\title{
Analysis of gender and leadership role competencies, perceptions and stereotypes in an organisational context
}

\author{
O.M. Samuel ${ }^{*}$ and I. Mokoaleli \\ School of Economic \& Business Sciences, University of the Witwatersrand, Johannesburg \\ *To whom all correspondence should be addressed \\ olorunjuwon.samuel@wits.ac.za
}

\begin{abstract}
Powell (1990) contended that the differences between women and men leadership style is mostly based on perception and stereotype and concluded that there are "no differences" between men and women managers. This article evaluated causal linkages between employees' perception of both managerial and functional competencies and stereotype of male and female managers using a conglomerate in South Africa. The study adopted survey strategy using quantitative research design. Respondents comprised of 383 conveniently sampled lower and middle level managers using the non-probability sampling technique. Using structural equation modelling (SEM) (AMOS) and inferential statistics, our analysis showed a positive association to establish that male managers are more competent than female managers $(t=21.01, p<01)$, while the SEM path between perceptions and managerial competence was found to be significant $(t=001<.05)$. We found a non-significant path between perceptions and functional competence $(t=.10, p>.05)$. Similarly, the path between perceptions and stereotyping was found to be non-significant $(t=.07>.05)$. This findings further extend contemporary literature on gender and leadership roles and perhaps provided some insights regarding the continued underrepresentation of women in executive and top management positions in various organisations.
\end{abstract}

\section{Introduction}

"Are female leaders better than their male counterparts in the management of organisations?" This has become a prevalent overarching debate in contemporary leadership literature. The debate, in itself stems from the stereotyping perception that has pervaded both organisational leadership literature and practice which suggests that males are more suitable and competent in managerial roles than their female counterparts (Eagly, Makhijani, \& Klonsky, 1992; Dobbins \& Platz, 1986). Gender-role stereotypes, i.e. the characterisation of certain jobs as predominantly masculine (e.g. engineering, construction) or feminine (e.g. catering/hospitality, nursing) is quite prevalent in society (Miller \& Budd, 1999) and more pronounced and firmly established in high-power distance culture as an acceptable normality (Jo Hatch \& Cunliffe, 2013). Managers, in the organisational context, are considered by their subordinates as leaders and managerial roles are characteristically masculine, rather than feminine (Schein, 2001). Other scholars (e.g. Eagly \& Karau, 2002) suggested that prejudice toward female leaders generally follows from the perceived incongruity between the characteristics of women and the requirements of leader roles. The authors further stated that such prejudices also varies, depending on the leadership context and more important, the characteristics of those who evaluates the leader. However, the relevance and indeed significance of the debate has been de-emphasised as there is no correlation between gender and managerial competence (Fierman, 1990). Nonetheless, the need still exist for researchers to further interrogate the phenomenon in order to arrive at scientifically established conclusions given the continued marginalisation and underrepresentation of women in top managerial positions (McGregor, 2010).

At this juncture, it is important to clarify two points upfront. The focus of this article is not predicated on men and women in biological terms, but on leadership roles within the context of social and contemporary organisational settings. Second, there is an overlap in the way that the terms leader and manager are used in many literature. Although there are some commonly accepted differences between leaders and managers (see, for example, Zaleznik, 2004), the terms are however used synonymously for the purpose of this article.

There is an avalanche of extant literature worldwide to establish the growing disparity in the advancement and representation of females occupying senior management positions in the work places relative to their male counterparts (Barreto, Ryan \& Schmitt, 2009; Burke, 2009; Burke \& Mattis, 2007; Helfat, Harris \& Wolfson, 2006; Tarr-Whelan, 2009). The experience is not different in South Africa. Women's managerial competence and ability are often underestimated, discounted and consistently evaluated against perceived standard achieved by their male counterparts (Hern, 2013). This seemingly superficial comparative managerial capability assumption has ultimately created a career progression difficulty for females who aspire to occupy executive and top managerial positions in different organisations (Wood, 2008). Empirical studies showed that only a little percentage of senior and executive management positions are occupied by women (Thornton, 2013) and this 
situation has remained static over a relatively long period of time. More concerning, according to Thornton's study is the regression in the percentage of females occupying management positions in South Africa which declined from an estimated $28 \%$ in 2009 to about $21 \%$ in 2013. Thornton's finding is consistent with evidence from the United States of America (USA) where males have traditionally occupied management positions in comparison to their female counterparts (Stelter, 2002). Further, the U.S. Bureau of Labor Statistics (2011) reported that women occupy a mere $3.8 \%$ of Fortune 500 chief executive officer seats (Catalyst, $2012 \mathrm{~b}$ ) and represent only $3.2 \%$ of the heads of boards in the largest companies of the European Union (European Commission, 2012 cited in Paustian-Underdahl et al., 2014).

The evidence presented in the preceding literature has been largely attributed to the negative perceptions surrounding women's ineffectiveness and inability to function effectively in leadership roles like their male counterparts (e.g. Carroll, 2006; Eagly, Makhijani, \& Klonsky, 1992; Deal \& Stevenson, 1998; Schein \& Davidson, 1993). Theoretical support for this perception have been provided in literature and they include lack of fit theory (Heilman, 2001), role congruity theory (Eagly \& Karau, 2002), expectation states theory (Berger et al., 1977; Ridgeway 2001, 2011), and the think manager-think male paradigm (Schein, 1973, 2007). Regardless of this theoretical support, there has been a growing debate and supporting arguments, particularly in the USA, suggesting that women are better advantaged and suited to lead and manage modern organisations than men (Paustian-Underdahl, Walker \& Woehr, 2014). According to Paustian-Underdahl and colleagues, this school of thought predicated their arguments on the likelihood that women are disposed to the adoption of collaborative and empowering leadership styles as opposed to men who are known for authoritative style of leadership.

The "women advantaged to lead" school of thought has received scholarly support from researchers such as Helgesen (1990) and Rosener (1995) who proposed that female leaders are more inclined to fulfil leadership need than men. The authors based their proposition on the inherent feminine characteristics of women, which, among others, emphasise interpersonal cooperation rather than competition on the one hand, and equality rather than a superior-subordinate authoritative relationship on the other hand. However, the basis of the position adopted by this school of thought has been criticised by some academic researchers as too "simplistic and offers a stereotype view that largely ignores the importance of contextual contingencies" (Eagly \& Carli, 2003a; Vecchio, 2002).

The primary objective of this paper therefore was to empirically test a conceptual model that depicted causal linkages between employees' perception of both managerial and functional competencies and stereotype of male and female managers using a large-sized conglomerate. In order to achieve this broad objective, we hypothesised as follows:

\begin{abstract}
H1: male managers are more competent than female managers at the organisation
\end{abstract}

H2: there is a linear relationship between employee perceptions and managerial competence at the organisation.

H3: there is a linear relationship between employee perceptions and functional competence at the organisation.

H4: there is a linear relationship between employee perceptions and stereotyping at the organisation.

The outcome of this study provided an empirical and methodological explanation to the recommendation by Eagly and Carli (2003a) and Vecchio (2002) that gender-role leadership studies should be contextualised using scientific methodology. This outcome thus represents an incremental contribution to the existing body of literature in organisational leadership and gender study, particularly within the context of South Africa.

After an in-depth study of the literature, a conceptual model was derived. Figure 1 illustrates the conceptual model that depicts the specific hypothesised causal linkages between perceptions, managerial competence, functional competence and stereotyping.

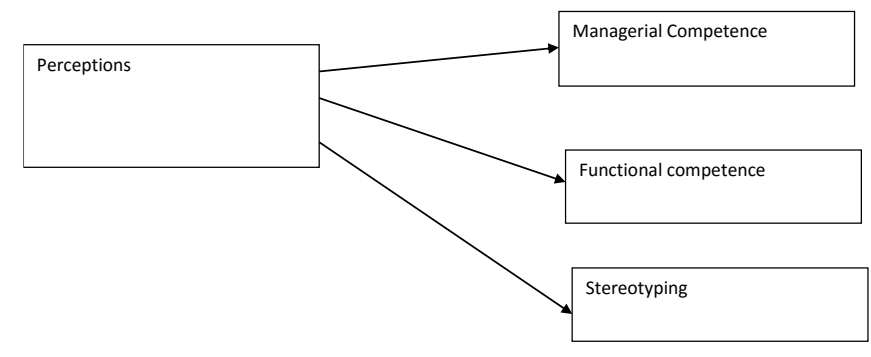

Figure 1: The conceptual model of the study

\section{Methods}

\section{Participants}

The study participants comprised 223 lower and 160 middlelevel management employees randomly sampled from a conglomerate operating in Johannesburg, South Africa. These categories of line managers are believed to have a good understanding of leadership concepts and are more familiar with the phenomenon under investigation. It is also believed that they are more exposed to the abilities and effectiveness demonstrated by their leaders in the course of exercising managerial functions (Sikdar \& Mitra, 2008). The conglomerate's diverse business operations include freight rail, port operations, pipelines and engineering. The gender profile of the respondents $(\mathrm{n}=383)$ comprised $69.3 \%$ males and $30.7 \%$ females. All the respondents possessed varied levels of tertiary education and have cumulative average work tenure of 3 years with the corporation. 


\section{Measurement instrument}

\section{Managerial competency scale}

The managerial competency component of the measuring instrument was measured using an adapted competency scale developed by Heilman and Okimoto (2007) and used in Patil (2009). The scale measured participants' evaluation of their female managers in comparison to their male counterparts. The competency Scale was divided into the following subscales: managerial ability, interpersonal skills, communality assessment, agenticism and personality.

The managerial ability of the scale consisted of three-item 5point Likert Scales: competent (ranging from $1=$ not very competent to $5=$ very competent $)$, effective $(1=$ not very effective to $5=$ very effective $)$, and productive $(1=$ not very productive to $5=$ very productive).

The interpersonal skills scale consisted of five-item 5-point Likert Scales with the following adjectives: abrasive $(1=$ not very abrasive to $5=$ very abrasive $)$, pushy ( $1=$ not very pushy to 5 = very pushy), untrustworthy $(1=$ not very untrustworthy to 5 = very untrustworthy), manipulative $(1=$ not very manipulative to $5=$ very manipulative $)$, and selfish $(1=$ not very selfish to $5=$ very selfish).

The communality scale consisted of four-item 5-point Likert Scales with the following adjectives: supportive $(1=$ not very supportive to $5=$ very supportive), understanding $(1=$ not very understanding to $5=$ very understanding $)$, sensitive ( $1=$ not very sensitive to $5=$ very sensitive $)$, and caring $(1=$ not very caring to $5=$ very caring). The measure of agenticism consisted of six-item 5-point Likert Scales with the adjectives: courageous $(1=$ not very courageous to $5=$ very courageous), assertive ( $1=$ not very assertive to $5=$ very assertive $)$, considerate $(1=$ not very considerate to $5=$ very considerate), bold $(1=$ not very bold to $=$ very bold $)$, active $(1=$ not very active to $=$ very active $)$, and dominant $(1=$ not very dominant to $=$ very dominant). The last component of the scale measured personality with a one-item 5-point Likert Scale with the adjective, likeable $(1=$ not very likeable to $5=$ very likeable).

The managerial competencies scale demonstrated strong internal consistency with a Cronbach's alpha values of $\quad(\alpha=$ .73) (Nunnally \& Bernstein, 1994).

\section{Functional competency scale}

Functional competence dimension was assessed with a selfdeveloped measuring scale using the guidelines provided by Harvard University's Faculty of Arts and Sciences, Department of Human Resources (http://hr.fas.harvard.edu/university-wide-competenciesand-rating-scales). The following aspects were assessed with a total of 35 questionnaire items measured on a 5-ponit Likert Aspects measured included: Knowledge of the job: ranging from $1=$ not knowledgeable to $5=$ very knowledgeable: knowledge of the job, policies, processes, practices, and tools required to complete the work efficiently and effectively. Achievement of results: 1 = very low understanding to $5=$ very high understanding of: how to leverage key resources to achieve organisational objectives, achieving goals and consistently meets deadlines timeously, monitors results and makes adjustments as needed and accepts responsibility for outcomes. Teamwork and collaboration: $1=$ actively participates to $5=$ not actively participates: as a team member to move the team toward the completion of goals, maintains strong, personal connections with key team members and stakeholders, aligns personal work and performance with the broader team to achieve mutual outcomes. Embraces change: $1=$ not very active to $5=$ very active: actively identifies problems and opportunities for change and implements solutions where appropriate, maintains effectiveness when experiencing major changes in work tasks or the work environment, adjusts effectively to work within new structures, processes, requirements or cultures. Resource allocation: $1=$ not efficient to $5=$ very efficient in: management of finances and organisational resources to enhance department/organisational goals, deployment of funds, human resources economically and effectively. Building a high performing team: $1=$ very effective to $5=$ not very effective in: developing a capable, diverse, and cohesive team to maximize their collective skills and talents; motivating subordinates to achieve the organisation's goals, recognition and rewarding individual and team contributions. Communication skills: $1=$ not very effective to $5=$ very effective in: listening skills and checks for understanding, demonstrating strong verbal and written communication, actively listening to subordinates' ideas and suggestions, informing subordinates of what is needed in a clear and concise manner, and consistently sharing appropriate information with those who need to know.

The functional competency scale equally demonstrated strong internal consistency with a Cronbach's alpha value of $(\alpha=.82)$ (Nunnally \& Bernstein, 1994).

\section{Perception scale}

The employees' perception of the managerial ability and effectiveness of their male and female managers was measured using 1) a modified and rephrased competency scale developed by Heilman and Okimoto (2007) and used in a study by Patil (2009); and 2) some dimensions of the functional competency scale used in this study. The 10-items used in the perception scale were derived from the subscales of managerial ability, interpersonal skills, personality, resource allocation, team building and communication skills. Some of the statements were rephrased to read as: "I perceived my male manager to be more competent than his female counterpart"; "I perceive that my male manager relates better with subordinates than his female counterpart"; "I perceive that my male manager is more efficient in allocating company's resources than his female counterpart"; "I perceive that my male manager communicate more effectively with subordinates than his female counterpart". Participants were asked to indicate their levels of agreement or disagreement with the questionnaire statement. The 
questions were phrased in a manner that required respondents to make a comparison between their male and female managers. Responses were measured on a Likert-type scale ranging from (5) strongly agree to (1) strongly disagree. The perception scale recorded a strong internal consistency with a Cronbach's alpha values of $(\alpha=.70)$ (Nunnally \& Bernstein, 1994).

\section{Stereotyping scale}

The six-item Beliefs of Women Managers scale (SBWMS) (Moore, Grundberg \& Greenberg, 2004) was used to measure stereotypes. We considered this Scale to be more appropriate for our study because the content focused specifically on the perceived evaluation-related differences between managerial men and women. Participants were asked to consider their beliefs and feelings toward women managers at the corporation that was surveyed and indicate their levels of agreement or disagreement with the questionnaire statement. The questions were phrased in a manner that required respondents to make a comparison between managerial men and women in the organisation. Responses were recorded on a Likert-type scale ranging from (1) strongly agree to (5) strongly disagree and were reverse scored so that a higher total score reflected greater levels of stereotyped belief (Moore et al. 2004). Internal consistency reliability for the revised 6-item scale is .91 .

\section{Procedure}

Questionnaire was administered to conveniently sampled lower and middle level managers at the surveyed organisation using the non-probability sampling strategy (Bryman \& Bell, 2011). The purpose of the study was explained in the cover letter to the substantive questionnaire. A total of 600 questionnaires were administered; while 406 were returned ( $68 \%$ return rate), only 383 of the returned questionnaires were usable. The problem of missing values was addressed through multiple imputations (Jöreskog \& Sörbom, 2006). The advantage of the multiple imputation procedures in structural equation modeling is that estimates of missing values are derived for all cases in the initial sample (i.e., no cases with missing values are deleted) and the data set is available for subsequent item and dimensionality analyses, and the formation of item parcels (Du Toit \& Du Toit, 2001; Mels, 2003). Data was collected from respondents over a period of 90 days by the authors with the assistance of two additional research assistants.

\section{Ethical considerations}

Ethical clearance was obtained from University of the Witwatersrand Ethics Committee. The respondents were duly informed of the purpose of the study through a cover letter which provided the rationale for the study (Malhotra, 2010). The cover letter also specified the participants' right to confidentiality, voluntary participation, and informed consent.

\section{Data analysis}

In order to validate the measurement model, the Cronbach`s alpha reliability coefficient, average variance extracted (AVE) and cross loadings were calculated. Item and dimensional analyses were conducted to determine the reliability and validity of the instruments as well as identify poor items.

\section{Results}

\section{Uni-dimensionality}

Both item and exploratory factor analyses were performed on the items of the scales used in the study. Based on the SPSS output on the item analysis, items 2, 4, and 7 of the functional competencies subscale were identified as poor items with an item total correlation below 0.3 (Pallant, 2010), and the deletion of the items increased the Cronbach's alpha coefficient from $\alpha=.553$ to $\alpha=.821$. The items were therefore excluded from further analyses. Generally, the results indicated that all the scores were above the .70 thresholds and therefore acceptable (Nunnally \& Bernstein, 1994; Pallant, 2010) (see Table 1).

Table 1: Reliability of constructs

\begin{tabular}{ll}
\hline Construct & $\begin{array}{l}\text { Cronbach`s } \\
\text { Alpha }\end{array}$ \\
\hline Functional Competencies & 0.821 \\
Managerial Competencies & 0.733 \\
Perceptions & 0.701 \\
Stereotyping & 0.908 \\
\hline
\end{tabular}

\section{Validity analysis}

The test for validity in the study was conducted through analysis of convergent and discriminant validity. The result indicated that all the constructs do have average variance extracted values of 0.6 and above, indicating that the constructs are adequately represented by their observed variables as they all have an average variance extracted (AVE) of at least 0.5 recommended by Henseler et al. (2009) (see Table 2). Discriminant validity was checked by using cross loadings after performing factor analysis. If an indicator has a higher correlation with another latent variable than with its respective latent variable, the appropriateness of the model should be reconsidered (Henseler et al., 2009). That was not the case in the study as all the latent variables correlates well with each other.

Table 2: Convergent and discriminant validity of constructs

\begin{tabular}{ll}
\hline \multicolumn{1}{c}{ Construct } & $\begin{array}{l}\text { Average Variance } \\
\text { Extracted }\end{array}$ \\
\hline Functional Competencies & 0.680 \\
Managerial Competencies & 0.598 \\
Perceptions & 0.647 \\
Stereotyping & 0.702 \\
\hline AVE (average variance extracted) for all three constructs
\end{tabular}




\section{Factor analysis}

Factor analysis using the orthogonal varimax rotation method was performed indicating the retention of four factors using the mineigen criterion. The total variance explained by the four factors was $72.02 \%$ as depicted in Table 3 . The factor loadings showed that each question loads higher on its own latent construct than on the others. The analysis of discriminant validity showed that each indicator is well correlated with the related construct. As a result, some of the questions relating to the construct had to be dropped as they did not load or match the significant component; thus only the driving forces were retained. From the results of Cronbach's alpha reliability coefficients, average variance extracted values and calculation of the cross loadings in the study, it is evident that the measurement model is valid.

Table 3: Factor loadings (in bold) and cross loadings for each construct and its indicators

\begin{tabular}{|c|c|c|c|c|}
\hline & $\begin{array}{l}\text { Functional } \\
\text { Competences }\end{array}$ & $\begin{array}{l}\text { Managerial } \\
\text { Competences }\end{array}$ & Stereotyping & Perceptions \\
\hline FC1 & 0.73983 & 0.09299 & -0.25127 & 0.02581 \\
\hline FC2 & 0.86711 & -0.01614 & -0.05616 & 0.07899 \\
\hline FC3 & 0.85803 & -0.08539 & -0.04406 & 0.03358 \\
\hline FC4 & 0.86972 & -0.01144 & -0.00387 & -0.06566 \\
\hline FC5 & 0.78107 & -0.00569 & 0.03059 & -0.01569 \\
\hline P1 & 0.03186 & -0.00907 & -0.07045 & 0.83389 \\
\hline P3 & 0.00019 & 0.21101 & 0.08834 & 0.77345 \\
\hline MC1 & -0.05735 & 0.89629 & 0.09069 & 0.02401 \\
\hline MC2 & -0.01918 & 0.89493 & 0.11132 & 0.07166 \\
\hline MC3 & 0.01129 & 0.81341 & 0.10471 & 0.16346 \\
\hline MC4 & 0.04251 & 0.81562 & 0.28133 & 0.01544 \\
\hline $\mathbf{S 2}$ & -0.04873 & 0.22357 & 0.82688 & -0.04486 \\
\hline S3 & -0.13660 & 0.19776 & 0.79425 & 0.05842 \\
\hline
\end{tabular}

\section{Measurement model factor loadings}

The completely standardised factor loading for the items contained in the overall measurement model exceeded the $>.50$ level (Hair, Black, Babin, \& Anderson, 2010). This implies that the item parcels reflect the dimension they were designed to represent.

\section{GFI indices for the structural model}

The GFI indices for the structural model indicated a reasonable model fit. The RMSEA value of .038 and p-value of .05 show good and close model fit to the data (see Table 2). The standardised RMR value of .050 is within the .06 cutoff level. The structural model GFI reached the .90 level required to indicate good fit (Diamantopoulos \& Siguaw, 2000) (see Table 5). The baseline comparison showed a NFI value $=0.948$. Also, RFI $=0.921, \mathrm{IFI}=0.988, \mathrm{TLI}=0.981$ and CFI $=0.987$ are all close to 1 , thus, indicating a very good fit of the model to the data (Diamantopoulos \& Siguaw, 2000) (see Table 6).

Table 6: Baseline comparison

\begin{tabular}{lllll}
\hline Model & RMR & GFI & AGFI & PGFI \\
\hline Default model & .050 & .954 & .919 & .545 \\
Saturated model & .000 & 1.000 & & \\
Independence model & .441 & .446 & .354 & .382 \\
\hline
\end{tabular}

SRMR: standardised root mean residual; GFI: goodness-of-fit; AGFI: adjusted goodness-of-fit index; PGFI:

\section{The structural model}

The four factor model was derived using AMOS (Analysis of Moment Structures) version 22 (see Figure 2).

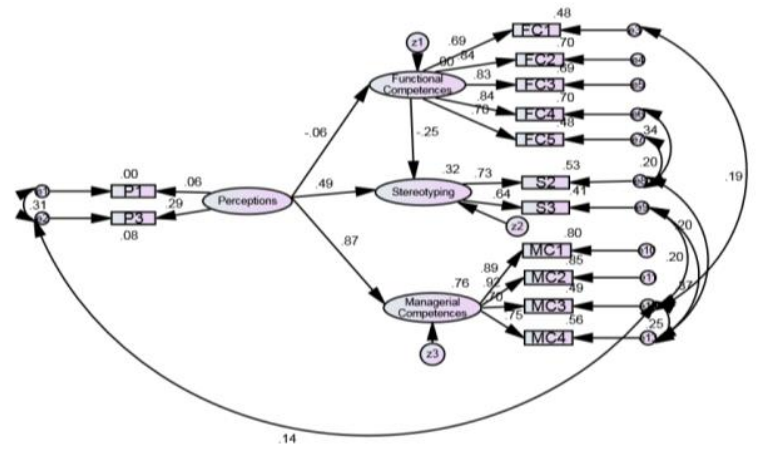

Functional competence (FC), Managerial competence (MC), Stereotyping (S), Perceptions (P).

Figure 2: The structural model of the study

\section{Significance tests of individual parameters}

The AMOS output shows the unstandardized regression coefficients. Each unstandardized regression coefficient represents the amount of change in the dependent variable for each unit change in the variable predicting it. The output also shows the unstandardized estimate, its standard error (S.E.) and the estimate divided by the standard error (Critical Ratio - C.R). The critical ratio is $>1.96$ demonstrating a significant path at the 0.05 level of significance. Also, under the p-value column, three asterisks $(* * *)$ indicated that an item is significant at $p<0.001$. It is evident from the results that all the paths (shown in colour) are not significant since their critical ratios are less than 1.96 and their $\mathrm{p}$-values are greater than 0.05 level of significance. Then the remaining paths (not shown in colour) are all significant since their critical ratios are greater than 1.96 and their $\mathrm{p}$-values are lesser than 0.05 level of significance (see Table 7). 
Table 7: Regression weights: (Group number 1 - Default model)

\begin{tabular}{|c|c|c|c|c|c|c|c|}
\hline & & & Estimate & S.E. & C.R. & $\mathbf{P}$ & Label \\
\hline Functional Competences & $\overline{<---}$ & Perceptions & -.131 & .195 & -.672 & .502 & \\
\hline Stereotyping & $<---$ & Perceptions & 1.298 & .453 & 2.864 & .004 & \\
\hline Managerial Competences & $<---$ & Perceptions & 2.427 & 1.362 & 1.782 & .075 & \\
\hline Stereotyping & $<---$ & Functional Competences & -.310 & .109 & -2.841 & .004 & \\
\hline P3 & $<--$ & Perceptions & 1.000 & & & & \\
\hline P1 & $<--$ & Perceptions & .205 & .256 & .798 & .425 & \\
\hline $\mathbf{S 2}$ & $<---$ & Stereotyping & 1.000 & & & & \\
\hline $\mathbf{S 3}$ & $<---$ & Stereotyping & .780 & .166 & 4.684 & $* * *$ & \\
\hline FC1 & $<---$ & Functional Competences & 1.000 & & & & \\
\hline FC2 & $<---$ & Functional Competences & 1.271 & .117 & 10.890 & $* * *$ & \\
\hline FC3 & $<--$ & Functional Competences & 1.185 & .109 & 10.836 & $* * *$ & \\
\hline FC4 & $<--$ & Functional Competences & 1.225 & .113 & 10.880 & $* * *$ & \\
\hline FC5 & $<---$ & Functional Competences & 1.111 & .121 & 9.191 & $* * *$ & \\
\hline MC1 & <--- & Managerial Competences & 1.000 & & & & \\
\hline MC2 & $<---$ & Managerial Competences & 1.125 & .064 & 17.547 & $* * *$ & \\
\hline MC3 & $<---$ & Managerial Competences & .745 & .063 & 11.882 & $* * *$ & \\
\hline MC4 & $<---$ & Managerial Competences & .914 & .070 & 12.965 & $* * *$ & \\
\hline
\end{tabular}

\section{Other key findings}

A positive association was found to establish that male managers are more competent than female managers $(\mathrm{t}=$ 21.01, $\mathrm{p}<01$ ), while the SEM path between perceptions and managerial competence was found to be significant $(\mathrm{t}=$ 001<.05). We found a non-significant path between perceptions and functional competence $(\mathrm{t}=.10, \mathrm{p}>.05)$. Similarly, the path between perceptions and stereotyping was found to be non-significant $(t=.07>.05)$.

\section{Discussion}

The purpose of this paper was to empirically investigate a linkage between leadership and gender-role and the influence of perceptions, competencies and stereotyping. The secondary objective was to test a conceptual model that depicted the structural relationships between the latent variables in the South African context. Regarding the fit of the model, the GFI indices indicated that both the measurement and the structural models produced good fit (see Table 5). The results indicated that the items measured the dimensions (latent variables) as postulated, as well as supported the theoretical model underlying the postulated relationships between the latent variables, i.e. perceptions, managerial competence, functional competence and stereotyping.

Documented evidence suggests that male managers are more effective/competent than their female counterparts (see Carroll, 2006; Eagly, Makhijani, \& Klonsky, 1992). Consistent with this body of literature, we found a positive relationship establishing that male managers are more competent than their female counterparts. This finding is further supported by several theoretical perspectives including lack of fit theory (Heilman, 2001), role congruity theory (Eagly \& Karau, 2002), expectation states theory (Berger et al., 1977; Ridgeway 1997, 2001), and the think manager-think male paradigm (Schein, 1973, 2007). Amongst others, Eagly and Karau's (2002) role congruity theory postulated that the prejudice toward female leaders emanate generally from the perceived incongruity between the characteristics of women (kind, caring, humble, communal, relations-oriented, and nurturing) and the agentic requirements of leader roles (decisive, risk-taking, autonomous, assertive) which are generally attributable to men. The role congruity theory was in part derived from the postulations of the social role theory, which argues that individuals develop descriptive and prescriptive gender role expectations of others' behaviour based on an evolutionary sex-based division of labour (Eagly, 1987; Eagly \& Wood, 2012). In its traditional characterisation of labour, men are expected to provide for the family's needs (breadwinners) while women are required to keep the home (homemakers) (Eagly \& Wood, 2012). Based on this gender role differentiation by the society, it has become an acknowledged and generally acceptable norms and values by individual members of the society to conform and act within the predetermined roles (Eagly, 1987).

The expectation theory (Ridgeway, 2001) provides a complementary support for the social theory. The theory (expectation) is underpinned by the social orientation that apportions greater power and status to males as compared to females, and expecting that male's performance in management and leadership roles should outweigh those of their female counterparts. This proposition is anchored on the belief that men are naturally embedded with superior power and status to influence and lead an organisation (Carli \& Eagly, 2001; Karakowsky \& Siegel, 1999; Ridgeway, 2001). The consequence of the social construct defining gender role within the society is such that women who occupy leadership positions are perceived to commit gender role violation (Eagly \& Karau, 2002).

Eagly et al. (1995) and Eagly and Karau (2002) posited that prejudice toward female leaders is also dependent on features of the leadership context as well as characteristics of leaders' evaluators. These authors' argument in itself was developed against the backdrop of the concept of tokenism (Kanter, 1977a) which postulated that sex ratios within the work group could moderate the outcome in the evaluation of gender - 
leadership role effectiveness. For instance, men may be seen as more effective leaders in a male-dominated environment/profession (Eagly et al., 1995; Eagly \& Karau, 2002) whereas the reverse perception may be the outcome where female raters are predominant. This leadership context and raters/evaluators' characteristics could have, perhaps combined in explaining the finding of this paper in this regard. The operational activities of the conglomerate that was surveyed for this study include engineering, rail freight, logistics and port operations. These are job terrains that are characteristically, socially and traditionally associated with men, and expectedly dominated by them $(69.3 \%$ males and $30.7 \%$ females). Our finding is therefore consistent with the argument of Eagly and Karau (2002) and further extends the negative perceptions of incongruity as it affects women leaders in certain work environments. However, a result of a meta-analysis conducted by Paustian-Underdahl et al. (2014) in male-dominated rater groups showed that women leaders were significantly more effective than their male counterparts, particularly in business and education related organisations. More pertinent in Paustian-Underdahl and colleagues finding was that women in senior-management positions were considered as more effective. The authors' finding was supported by a laboratory study by Rosette and Tost (2010) and Foschi's (2000) double standards of competence model which postulated the possibility that women occupying leadership positions are more effective than their male counterparts due to perceptions of their 'extra competence'. The deductions in Paustian-Underdahl et al. (2014), Rosette and Tost (2010) and Foschi (2000) reflect a seeming reversal of gender-role stereotypes to the effect that women are considered to be more effective leaders than men (see Koenig et al., 2011). The establishment of this perceived shift in historical stereotyping may however require further research across a wide spectrum of organisations and cultural context.

Extant literature suggests that application of leadership and managerial competencies is universal across industry and function (Boyatzis, 2011; Spencer \& Spencer, 1994; Lombardo \& Eichinger, 2005). Competencies generally entail the ability to apply acquired knowledge and other capabilities that are necessary for the efficient performance and achievement of predetermined organisational goals (Gruban, 2003). Thus, the type of managerial competency required in a male dominated industries, for example, mining, manufacturing and construction is not different from the one demonstrated in a seemingly female dominated industries, for example, nursing, healthcare, catering and hospitality (Dainty, Cheng \& Moore, 2004; Arditi, Gluch \& Holmdahl, 2013; Dreyfus, 2008; Barber \& Tietje, 2004). This argument is indeed consistent with the definition of managerial competency which is a set of knowledge, skills, abilities and behaviours that enables effective performance and achievement of set organisational outcomes (Hellriegel, Jackson, Slocum, Staude, Amos, Klopper, Louw \& Oosthuizen, 2004; Campion, et. al., 2011; Vakola, Soderquist \& Prastacos, 2007; Levenson, Van der Stede \& Cohen, 2006; Laguna, Wiechetek \& Talik, 2012; Wickramasinghe \& De Zoyza, 2009; Singh \& Khamba, 2014; Barber \& Tietje, 2004; Boyatzis, 2011). These managerial competencies are transferable from one organisation to another due to its universal nature (Hellriegel et al., 2004).

In furthering the debate around differences in managerial competencies between genders, Donnell and Hall (1980) found that there is no difference in the way women practice management compared to men. Powell (1990) concurred with Donnell and Hall and concluded that whatever differences that are reported between women and men managers are based on perception and stereotype. In their own study, Arditi, Gluch and Holmdahl (2013) found differences in the competencies of men and women, but also reported many similarities. These differences reflect the historical perceptions about men and women leaders and managers (Tomal \& Jones, 2015; Dobbins \& Platz, 2006). Given the near convergence of literature establishing that there is no difference in managerial competencies between men and women managers, our instant study could not have produced a different outcome. This consistency with extant literature thus explains the significant SEM path $(\mathrm{t}=001<.05)$ between perceptions and managerial competence as proposed in this study (Hypothesis 2). Respondents in this study agreed that both male and female managers in the organisation demonstrated the same level of core competencies (i.e. managerial ability, interpersonal skills, communality assessment, agenticism \& personality) that were required in achieving predetermined organisational goals.

Although functional competencies are generally attributed to middle-level or operational-level managers, it is nevertheless required for a successful performance at top-level management positions. This category of competence represents job-specific competencies that drive proven highperformance and quality results in organisations (Sturgess, 2012). Functional competencies could be acquired through formal qualifications and skills acquired during targeted training. This competency is required for problem solving and notably include language and communication skills, multicultural skill, technological and globalisation skills (Manning, 2003; May, 1997; Jokinen, 2005; Suutari, 2002; Harris, 2001). While it is important for line or operational managers to possess technical expertise in order to achieve results, middle-level and top level managers require greater people management, conceptual and strategic competencies respectively (Robbins, Bradley \& Spicer, 2001; Wallick \& Stager, 2001). A survey of Chief Executive Officers conducted by Karami (2011) identified human resources management capability as a core competency in order to achieve competitive advantage and attain overall organisational success. Karami's finding is consistent with previous studies by Dyer and Reeves (1995) and Analoui (1999a). This body of knowledge thus establishes HR capability as a functional competency that is required by top level managers for the effective execution of strategic functions.

As suggested in the foregoing literature (see Robbins et al., 2001; Wallick \& Stager, 2001), top level managers require greater dimension of people management, conceptual and strategic competencies than functional competence. This indication perhaps explain the non-significant path between 
perceptions and functional competence $(\mathrm{t}=.10, \mathrm{p}>.05)$ found in the present study thus rejecting Hypothesis 3 (as stated). Unlike in the outcome between perception and managerial competencies where respondents indicated their preferences for a male manager (see Hypothesis 2), no particular importance was attached to functional competence of managers at the organisation. Similarly, the outcome in perception on functional competence did not enjoy significant literature support as most existing studies were concentrated on operational or line managers, rather than top level managers. For example, Mbokazi and Visser (2004) found significant differences between the perceptions of male and female managers with regard to the interpersonal, analytical and operational competencies. Previous studies also indicated that while male managers perceived themselves as strong in the task-management competencies (Mbigi, 1994; Segal, 1991), and their female colleagues in interpersonal competencies (Adler, 1994; Van der Merwe, 1994), both parties do not necessarily perceive these competencies to be especially important for the effectiveness of both middle and top-level managers.

The outcome of several early seminal studies directed at the differences in perceived stereotypical leadership role between men and women generally indicated that men are perceived as better suited than women (Nieva \& Gutek, 1981). This stereotypical perceptions have pervaded classical studies such as Bowman, Worthy and Greyser (1965, p. 28) which indicated that women are "temperamentally unfit" for managerial positions. Such studies mostly derived theoretical support from the role congruity theory which explained gender stereotyping of leadership positions by positing that perceived gender roles may conflict with expectations regarding leadership roles, especially when an occupation is held predominantly by one sex (Eagly et al., 1995). Gender stereotyping has been defined as "the belief that a set of traits and abilities is more likely to be found among one sex than the other" (Schein, 1978, p. 259) and are considered one of the direct antecedents of discrimination at work (Dovidio \& Hebl, 2005). This stereotyping tendency has been extended to occupations that are perceived to be traditionally exclusive to men or women (Eagly \& Johnson, 1990; Norris \& Wylie, $1995)$ as explained in the section above. This characterisation could potentially strengthen stereotypes that women are less qualified than men for leadership roles in these perceived 'classified' occupations (e.g. engineering, mining, military, construction, etc.) and this can have far-reaching implications for recruitment, selection, placement, performance evaluations and promotions (Norris \&Wylie, 1995; Youngman, 2001).

Notwithstanding the various initiatives and measures by government and society aimed at increasing women participation in leadership roles (e.g. affirmative action, employment equity legislation, gender equality policy), the traditional stereotypes remain. These stereotypes could potentially account for the disparity in the number of men and women occupying leadership position in contemporary South African organisations. In 2001, South Africa introduced a framework that promotes equality amongst both genders with the aim of increasing the number of women in the decision making structure (Chiloane-Tsoka, 2012). This initiative has however not achieved the desired result as a report by The Commission of Employment Equity (2012) shows that males continue to dominate top management positions in various organisations. While a number of studies (e.g. (Dodge, Gilroy \& Fenzel, 1995; Norris \& Wylie, 1995; Schein, Mueller, \& Jacobson, 1989) have demonstrated stereotypical masculine traits (by men) in the characterisation of successful managers, others (e.g. Schein, 1975) has depicted female managers accepting stereotypical masculine characteristics as a model for success in management. This characterisation by female managers thus imply their acceptance of the traditional male-dominance culture and could influence their selection, promotion and placement decisions in favour of men. This evidence could therefore lead to the conclusion that women are at least partially to blame both for their own difficulty in attaining leadership positions and for society's lukewarm attitude to accept them. As a consequence of the stereotypical perception that women do not characteristically fit into leadership model, women who want to be leaders are usually required to be extremely well qualified, have proven records of accomplishments, and work harder than their male counterparts in order to be accepted as leaders (Moran, 1992).

Although the above literature clearly demonstrates that gender stereotypes are prevalent in organisations as a potential barrier to advancement, the degree of its persistence in the 21 st century remain unclear (Duehr \& Bono, 2006). Literature suggest a gradual change in the social environment as the distribution of men and women into social roles is shifting thus influencing the perceptions of stereotypes (Lueptow et al., 2001). This environmental change, particularly for female managers, could be attributed to two possibilities: first, the changing social roles (e.g. increasing education and participation of women at work and in managerial and executive positions); and second, compelling legal requirements on organisations to embrace diversity and achieve gender equality (Duehr \& Bono, 2006).

Notably also is the emergence of studies that provided empirical support for the 'women advantage to lead' school of thought (Helgesen, 1990; Rosener, 1995) articulated in an earlier section of this paper. Such support could be found in a meta-analytical study conducted by Koenig, Eagly, Mitchell and Ristikari (2011). The study examined the extent to which stereotypes of leadership are culturally masculine and concluded that contemporary leadership seemingly "incorporate more feminine relational qualities, such as sensitivity, warmth, and understanding" (p. 634). To this extent, Koenig and colleagues contended that organisations should shift emphasis away from the traditional masculine view of leadership towards a more feminine and transformational outlook. The successful emergence of women leaders in traditionally dominated fields such as politics and business has lent some credibility to Koenig et al. study. Contemporary female political leaders include Angelo Merkel, Hillary Clinton, Dilma Rousseff, while the field of business consists of personalities such as Vera Songwe, Bola Shagaya, Maria Ramos and Sibongile Sambo. This evidence aptly demonstrates that leadership quality is not an exclusive function of masculinity. The changing socio-legal 
environment coupled with the emerging shift in perceptions and stereotypes regarding gender characterisation of leadership roles in contemporary organisations also provides explanation for the non-significant path that was found between perceptions and stereotyping $(t=.07>.05)$ in the current study.

\section{Conclusion}

The current study contributes empirically to the genderleadership roles literature by evaluating the causal linkages among managerial and functional competencies, perceptions and stereotyping. Although the statistical analysis of the study supports the age long assertion that male managers are more competent than their female managers in exercising managerial competence, this finding was explained within the context provided by Eagly et al. (1995) and Eagly and Karau (2002) to the extent that prejudice toward female leaders is dependent on features of the leadership context as well as characteristics and biases of the evaluators. Although this study provides support in terms of gender characterisation and a changing debate and literature suggesting that when all leadership contexts are considered together, there is a nonsignificant gender difference in leadership effectiveness. More important, the conceptual model that was developed and validated in this this study provides a framework for future studies in the areas of leadership and gender roles, organisational competency, perception and stereotyping.

\section{References}

Adler, N. J. 1994. 'Competitive frontiers: Women managing across borders', Journal of Management Development, 13(2): 24-41.

Analoui, F. 1999. 'Eight parameters of managerial effectiveness: a study of senior managers in Ghana', Journal of Management Development, 18(4): 362-390.

Arditi, D., Gluch, P. \& Holmdahl, M. 2013. 'Managerial competencies of female and male managers in the Swedish construction industry', Construction Management and Economics, 31(9): 979-990.

Barber, C.S. \& Tietje, B.C. 2004. 'Competency requirements for managerial development in manufacturing, assembly, and/or material processing functions', Journal of Management Development, 23(6): 596-607.

Barreto, M. E., Ryan, M. K., \& Schmitt, M. T. 2009. The glass ceiling in the 21st century: Understanding barriers to gender equality. American Psychological Association. Washington DC, 2147. [online] http://dx.doi.org/10.1037/11863-002.

Berger, J., Fisek, M.H., Norman, R.Z. \& Zelditch, M. 1977. Status characteristics and social interaction. New York: Elsevier Scientific.

Bowman, G.W., Worthy, N.B. \& Greyser, S.A. 1965. 'Are women executives people?' Harvard Business Review, 43(15-28): 164-178.

Boyatzis, R.E. 2011. 'Managerial and leadership competencies: A behavioral approach to emotional, social and cognitive intelligence', Vision: The Journal of Business Perspective, 15(2): 91-100.
Bryman, A. \& Bell, E. 2011. Business research methods (3rd Ed.). Oxford, UK: Oxford University Press.

Burke, P. 2009. Popular culture in early modern Europe. Ashgate Publishing Ltd.

Burke, S. \& Collins, K.M. 2001. 'Gender differences in leadership styles and management skills', Women in Management Review, 16: 244-257.

Burke, R. J., \& Mattis, M. C. (Eds.). 2007. Women and minorities in science, technology, engineering, and mathematics: Upping the numbers. Edward Elgar Publishing.

Campion, M.A., Fink, A.A., Ruggeberg, B.J., Carr, L., Phillips, G. M. \& Odman, R.B. 2011. 'Doing competencies well: Best practices in competency modelling, Personnel Psychology, 64(1): 225-262.

Carli, L.L. \& Eagly, A.H. 2001. 'Gender, hierarchy, and leadership: An introduction', Journal of Social Issues, 57(4):629-636.

Carroll, J. 2006. Americans prefer male boss to a female boss. [online] http://brain.gallup.com.

Catalyst. 2012b. U.S. women in business. [online] www.catalyst.org/knowledge/us-women-business-0.

Chiloane-Tsoka, E.G. 2012. 'Cultural observations facing women managers: A South African perspective', Gender \& Behaviour, 10(2): 4949-4973.

Dainty, A.R., Cheng, M.I. \& Moore, D.R. 2004. 'A competencybased performance model for construction project managers', Construction Management and Economics, 22(8): 877-886.

Deal, J.J. \& Stevenson, M.A. 1998. 'Perceptions of female and male managers in the 1990s: Plus ca change', Sex Roles, 38(3): 287-300.

Diamantopoulos, A., Siguaw, J. A., \& Siguaw, J. A. 2000. Introducing LISREL: A guide for the uninitiated. Sage.

Dobbins, G.H. \& Platz, S.J. 1986. 'Sex differences in leadership: How real are they?' Academy of Management Review, II(1):118-127.

Dodge K.A, Gilroy, F.D. \& Fenzel, L.M. 1995. 'Requisite management characteristics revisited: Two decades later', Journal of Social Behavior \& Personality, 10: 253-264.

Donnell, S.M. \& Hall, J. 1980. 'Men and women as managers: A significant case of no significant differences', Organizational Dynamics, (Spring): 60-76.

Dovidio, J.F. \& Hebl, M.R. 2005. Discrimination at the level of the individual: Cognitive and affective factors. In Dipboye RL, Colella A (Eds.), Discrimination at work (pp. 11-35). Mahwah, NJ: Erlbaum.

Dreyfus, C.R. 2008. 'Identifying competencies that predict effectiveness of R\&D managers', Journal of Management Development, 27(1): 76-91.

Duehr, E.E. 2006. Personality, gender, and transformational leadership: Investigating differential prediction for male and female leaders. Unpublished doctoral dissertation, University of Minnesota. 
Du Toit, M. \& Du Toit, S.H.C. 2001. Interactive LISREL: User's guide. Lincolnwood, IL: Scientific Software International.

Dyer, L. \& Reeves, T. 1995. 'Human resource strategies and firm performance', The International Journal of Human Resource Management, 6(3): 656-657.

Eagly, A.H. 1987. Sex differences in social behavior: A social-role interpretation. Hillsdale, NJ: Erlbaum.

Eagly, A.H. \& Wood, W. 2012. Social role theory. In P. van Lange, A. Kruglanski \& E. T. Higgins (Eds.), Handbook of theories in social psychology (pp. 458-476). Thousand Oaks, CA: Sage.

Eagly, A.H. \& Karau, S.J. 2002. 'Role congruity theory of prejudice toward female leaders', Psychological Review, 109: 573-598.

Eagly, A.H. \& Carli, L.L. 2003a. 'The female leadership advantage: An evaluation of the evidence', Leadership Quarterly, 14: 807-834.

Eagly, A.H. \& Johnson, B.T. 1990. 'Gender and leadership style: A meta-analysis', Psychological Bulletin, 108, 233-256.

Eagly, A.H., Karau, S.J. \& Makhijani, M.G. 1995. 'Gender and the effectiveness of leaders: A meta-analysis', Psychological Bulletin, 117: $125-145$.

Eagly, A., Makhijani, M. \& Klonsky, B. 1992. 'Gender and the evaluation of leaders: A meta-analysis', Psychological Bulletin, 111: 3-22.

Eichinger, J. 2005. 'Using Models Effectively', Science and Children, 42(7): 43-45.

Fierman, J. 1990. 'Why women still don't hit the top', Fortune, July 30: $40-62$

Foschi, M. 2000. 'Double standards for competence: Theory and research', Annual Review of Sociology, 26: 21-42.

Gruban, B. 2003. 'Kompetence: moda, ki traja že štiri desetletja', Finance, 168(1596): 19.

Hair, J.F., Black, W.C., Babin, B.J. \& Anderson, R.E. 2010. Multivariate data analysis: A global perspective ( $7^{\text {th }}$ Ed.). Upper Saddle River, NJ: Pearson.

Harris, P.R. 2001. 'Ensuring European leadership in the global marketplace', European Business Review, 13(6): 336-345.

Harvard University: Faculty of Arts \& Science, Department of Human Resources (date unknown). Competencies and Rating Scales. [online] hr.fas.harvard.edu/university-wide-competenciesand-rating-scales.

Hatch, M. J., \& Cunliffe, A. L. 2013. Organization theory: modern, symbolic and postmodern perspectives. $3^{\text {rd }}$ Edition. Oxford: Oxford university press.

Hebl, M. R., \& Dovidio, J. F. 2005. 'Promoting the "social" in the examination of social stigmas', Personality and Social Psychology Review, 9(2): 156-182.

Heilman, M.E. 2001. 'Description and prescription: How gender stereotypes prevent women's ascent up the organizational ladder', Journal of Social Issues, 57: 657-674.
Heilman, M. E., \& Okimoto, T. G. 2007. 'Why are women penalized for success at male tasks'? The implied communality deficit', Journal of Applied Psychology, 92(1): 81-92.

Helfat, C. E., Harris, D., \& Wolfson, P. J. 2006. 'The pipeline to the top: Women and men in the top executive ranks of US corporations', The Academy of Management Perspectives, 20(4): $42-64$.

Helgesen, S. 1990. The female advantage: Women's ways of leadership. New York: Doubleday.

Hellriegel, D., Jackson, S.E., Slocum, J.W., Staude, G., Amos T., Klopper, H.B., Louw, L. \& Oosthuizen, T. 2004. Management. $2^{\text {nd }}$ South African Edition. Cape Town: Oxford University Press.

Henseler, J., Ringle, C.M. \& Sinkovics, R.R. 2009. The Use of Partial Least Squares Path Modeling in International Marketing. In

Sinkovics, R. R. \& Ghauri, P. (Ed.). Advances in International Marketing. Bingley: Emerald Group Publishing Limited.

Hern, J. 2013. 'Not enough women in senior management positions in South Africa', [online] www.gt.co.za/news/2013/03/not-enoughwomen-in-senior-management-positions-south-africa.

Jokinen, T. 2005. 'Global leadership competencies: A review and discussion', Journal of European Industrial Training, 29(3): 199216.

Joreskog, K.G. \& Sorbom, D. 2006. LISREL 8.80 for Windows [Computer Software]. Lincolnwood, IL: Scientific Software International.

Kanter, R. 1977. 'Some effects of proportions on group life: Skewed sex ratios and responses to token women', American Journal of Sociology, 82: 965-990.

Kanter, R. 1977a. Men and women of the corporation. New York, NY: Basic Books.

Karakowsky, L., \& Siegel, J. P. 1999. 'The effects of proportional representation and gender orientation of the task on emergent leadership behavior in mixed-gender work groups', Journal of Applied Psychology, 84(4): 620.

Karami, A. 2011. 'How human resource capabilities affect the organisations' performance?' The case of electronic industry in the U.K. A research paper presented at The Fifth European Conference on Organizational Knowledge, Learning and Capabilities, Centre of Strategic Management \& Leadership, University of Innsbruck, April 1-3, 2011, Innsbruck, Austria.

Koenig, A.M., Eagly, A.H., Mitchell, A.A. \& Ristikari, T. 2011. 'Are leader stereotypes masculine? A meta-analysis of three research paradigms', Psychological Bulletin, 137(4): 616.

Laguna, M., Wiechetek, M. \& Talik, W. 2012. 'The Competencies of Managers and Their Business Success', Central European Business Review, 1(3): 7-13.

Levenson, A.R., Van der Stede, W.A. \& Cohen, S.G. 2006. 'Measuring the relationship between managerial competencies and performance', Journal of Management, 32(3): 360-380.

Lombardo, M.M. \& Eichinger, R.W. 2005. The leadership machine. Minneapolis, MN: Lominger. 
Lueptow, L.B., Garovich-Szabo, L. \& Lueptow, M. 2001. 'Social change and the persistence of sex typing 1974-1997', Social Forces, 80: $1-35$.

Mbigi, L. 1994. The spirit of African management. Christie, Lessem \& Mbigi. African Management: Philosophies, concepts and applications. Randburg: Knowledge Resources.

McGregor, J. 2010. China's drive for 'indigenous innovation. Global Regulatory Cooperation Project and US Chamber of Commerce. [online] http://www. uschamber. Com/sites/default/files/reports.

Malhotra, D. 2010. 'The desire to win: The effects of competitive arousal on motivation and behavior', Organizational Behavior and Human Decision Processes, 111(2): 139-146.

Manning, T.T. 2003. 'Leadership across cultures: Attachment style influences', Journal of Leadership \& Organizational Studies, 9(30):20-30.

May, A.S. 1997. 'Think globally - act locally! Competences for global management', Career Development International, 2(6): 308311.

Mbokazi, B. \& Visser, L. 2004. 'Management perceptions of competencies essential for middle managers', SA Journal of Industrial Psychology, 30(1): 1-9.

Medveš, Z. 2006. 'Informativni in formativni nivo v kurikularnem nacrtovanju', Vzgoja in izobraževanje, 37(1):19-21.

Miller, L. \& Budd, J. 1999. 'The development of occupational sexrole stereotypes, occupational preferences and academic subject preferences in children at ages 8, 12, and 16', Educational Psychology, 19(1):17-35.

Moore, S, Grundberg, L. \& Breenberg, E. 2004. 'Development and validation of a scale to measure beliefs about women managers', Current Psychology, 23(3): 245-256.

Moran, B.B. 1992. 'Gender differences in leadership', Library Trends, 40(3): 475-91.

Nieva, V.F. \& Gutek, B.A. 1981. Women and work. New York: Praeger.

Norris, J. M., \& Wylie, A. M. 1995. 'Gender stereotyping of the managerial role among students in Canada and the United States', Group \& Organization Management, 20(2): 167-182.

Nunnally, J.C. \& Bernstein, I.H. 1994. Psychometric theory (3rd Ed.). New York: McGraw-Hill.

Pallant, J. 2010. SPSS survival manual: A step by step guide to data analysis using SPSS (4th Ed.). London, England: McGraw-Hill.

Patil, S. 2009. 'Male-dominated industries: Effects of gender rarity, performance, and diversity justification', Michigan Journal of Business, 2(1): 39-79.

Patil, S. 2011. 'Perceptions of female managers in male-dominated industries: Effects of gender rarity, performance, and diversity justification', Michigan Journal of Business, 2(1): 39-62.

Paustian-Underdahl, S.C., Walker, L.S. \& Woehr, D.J. 2014. 'Gender and perceptions of Leadership Effectiveness: A meta- analysis of contextual moderators', Journal of Applied Psychology, 99(6): 1129-1145.

Powell, G. N. 1990. 'One more time: Do female and male managers differ'? The Executive, 4(3): 68-75.

Powell, G.N., Butterfield, D.A. \& Parent, J.D. 2002. 'Gender and managerial stereotypes: Have the times changed'? Journal of Management, 28: 177-193.

Ridgeway, C. L. 1997. 'Interaction and the conservation of gender inequality: Considering employment', American Sociological Review, 218-235.

Ridgeway, C. 2011. Framed by gender: How gender inequality persists in the modern world. New York: Oxford University Press.

Ridgeway, C.L. 2001. 'Gender, status, and leadership', Journal of Social Issues, 57: 637-655.

Robbins, C.J, Bradley, E.H. \& Spicer, M. 2001. 'Developing leadership in health care administration: A competency assessment tool', Journal of Healthcare Management, 46(3): 188-202.

Rosener, J.B. 1995. America's competitive secret: Utilizing women as a management strategy. New York: Oxford University Press.

Rosette, A.S. \& Tost, L.P. 2010. 'Agentic women and communal leadership: How role prescriptions confer advantage to top women leaders', Journal of Applied Psychology, 95(2):221-235.

Schein, V.E. 1973. 'The relationship between sex role stereotypes and requisite management characteristics', Journal of Applied Psychology, 57:95-100.

Schein, V.E. 1975. 'Relationships between sex role stereotypes and requisite management characteristics among female managers', Journal of Applied Psychology, 60: 340-344.

Schein,V.E. 1978. 'Sex role stereotyping, ability, and performance: Prior research and new directions', Personnel Psychology, 31: 259268.

Schein, V.E., Mueller, R. \& Jacobson, C. 1989. 'The relationship between sex role stereotypes and requisite management characteristics among college students', Sex Roles, 20: 103-110.

Schein, V. E., \& Davidson, M. J. 1993. 'Think manager, think male', Management Development Review, 6(3): 24-28.

Schein, V. E. 2001. 'A global look at psychological barriers to women's progress in management', Journal of Social issues, 57(4): 675-688.

Schein, V.E. 2007. 'Women in management: Reflections and projections', Women in Management Review, 22: 6-18.

Segal, B. 1991. Women in computing: elected papers, 1988-1990. London: Springer-Verlag.

Sikdar, A \& Mitra, S. 2008. An exploration of gender stereotypes on perception and practice of leadership. University of Wollongong (Dubai) Management Working Paper Series (WP 79/2008).

Singh, C.D. \& Khamba, J.S. 2014. 'Evaluation of manufacturing competency factors on performance of an automobile manufacturing 
unit', International Journal for Multi-Disciplinary Engineering and Business Management, 2(2): 4-16.

Spencer, L.M. Jr. \& Spencer, S.M. 1993. Competence at work: models for superior performance. New York: John Wiley \& Sons.

Sturgess, G. 2012. Skills vs competencies. What's the difference? Talent Align. [online] www.talentalign.com.

Stelter, N. Z. 2002. 'Gender differences in leadership: Current social issues and future organizational implications', Journal of Leadership \& Organizational Studies, 8(4): 88-99.

Suutari, V. 2002. 'Global leader development: an emerging research agenda', Career Development International, 7(4): 218-233.

Svetlik, I.O., kompetencah, V. \& Pezdirc, M. S. 2005. Kompetence v kadrovski praksi, pp.12-27. Ljubljana: GV izobraževanje.

The Republic of South Africa. 2010. Department of Labour: Tenth Commission of Employment Equity Annual Report - 2009 - 2010. Pretoria: Government Printers.

Tarr-Whelan, L. 2009. Women lead the way: Your guide to stepping up to leadership and changing the world. Berrett-Koehler Publishers.

Thornton, A. 2013. Reading history sideways: The fallacy and enduring impact of the developmental paradigm on family life. University of Chicago Press.

Tomal, D.R. \& Jones, K.J. 2015. 'A comparison of core competencies of women and men leaders in the manufacturing industry', The Coastal Business Journal, 14(1):13-25.

U.S. Bureau of Labor Statistics. 2011. Household data annual averages: 11. Employed persons by detailed occupation, sex, race, and Hispanic or Latino ethnicity. [online] www.bls.gov/cps/cpsaat11.pdf.

Vakola, M., Soderquist, K.E. \& Prastacos, G.P. 2007. 'Competency management in support of organizational change', International Journal of Manpower, 28(3/4): 260-275.

Van der Merwe, L. 1994. 'A learning community with a common purpose. In Christie, Lessem \& Mbiki (Eds.). African Management: Philosophies, concepts and applications. Randburg: Knowledge Resources.

Wickramasinghe, V. \& De Zoyza, N. 2009. 'A comparative analysis of managerial competency needs across areas of functional specialization', Journal of Management Development, 28(4): 344360.

Vecchio, R.P. 2002. 'Leadership and gender advantage', Leadership Quarterly, 13: 643-671.

Wallick W.G \& Stager K.J. 2001. 'Healthcare managers' roles, competencies and outputs in organisational performance improvement/practitioner response', Journal of Healthcare Management, 47(6): 390-402.

Wood, G. 2008. 'Gender stereotypical attitudes: Past, present and future influences on women's career advancement', Equal Opportunities International, 27(7):613-628.
Youngman, J. 2001. Women in the military: The struggle to lead. In C.B. Costello \& A.J. Stone (Eds.), The American woman 20012002: Getting to the top (pp. 139-168). New York: Norton.

Zaleznik, A. 2004. 'Managers and leaders: Are they different?', Harvard Business Review, 82(1): 74-81. 